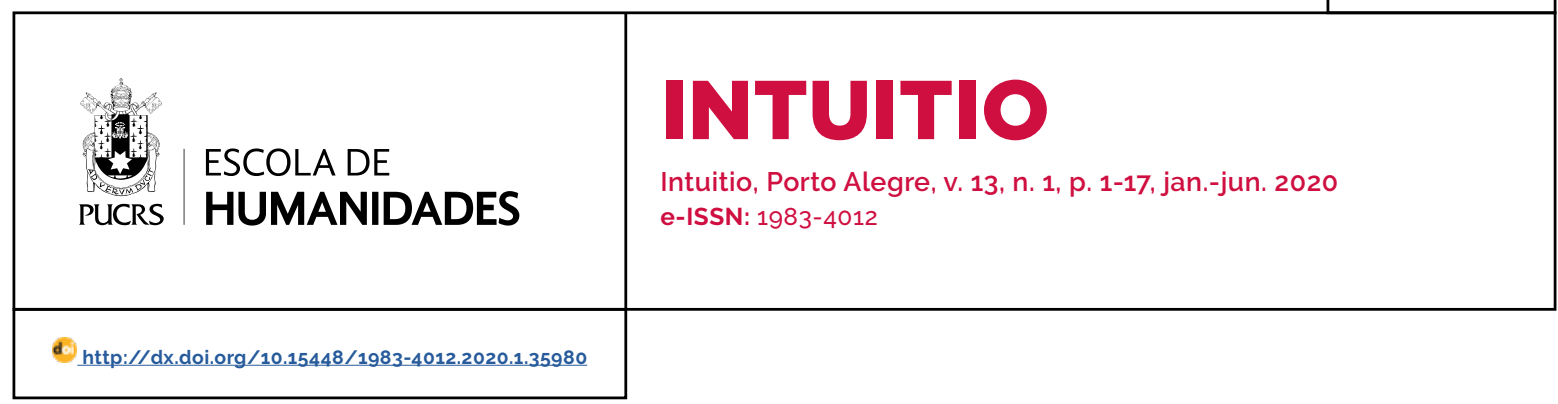

SEÇÃO: VARIA

\title{
Impulsionando a lei moral: o lugar sistemático da antropologia no interior da filosofia prática
}

\author{
Promoting the moral law: the systematic place of anthropology in practical philosophy
}

\author{
Felipe Rodrigues \\ Simões ${ }^{1}$ \\ orcid.org/0000-0002-1496-6020 \\ profo.felipe@gmail.com
}

Recebido em: 15 out. 2019

Aprovado em: 25 nov. 2019.

Publicado em: 27 jul. 2020.

\section{(c) (i)}

Artigo está licenciado sob forma de uma licença Creative Commons Atribuição 4.0 Internacional.
Resumo: O presente artigo pretende apontar a problemática da antropologia e sua relação com a filosofia prática no pensamento de Immanuel Kant (1724-1804). O trabalho, desse modo, não apenas tenciona retomar os pontos centrais que estruturam a parte pura da ética kantiana (entendida como filosofia da liberdade), mas também busca chamar a atenção para sua parte impura, a saber: o "homem empírico" e a "consciência moral comum". Logo, embora uma metafísica dos costumes não possa ser fundada empiricamente, a posição de Kant será a de que poderiamos, pelo menos, realizá-la nesse âmbito, descle que observadas e descritas, por meio "das diferentes doutrinas da razão prática pura", as condições pelas quais a "ação humana do indivíduo, dos grupos e da própria espécie" encontram-se amparadas. As implicações disso, contudo, não serão propriamente tratadas em sua totalidade, mas introduzidas segundo a ordem de importância necessária à construção do que Kant denominou como sendo "um sistema da liberdade semelhante a um sistema da natureza".

Palavras-chave: Kant. Antropologia. Moral. Natureza.

Abstract: The paper aims to point out the anthropology problem and its relation with the practical philosophy in the thought of Immanuel Kant (1724-1804). The work not only intends to return to the central points that structure the pure part of Kantian ethics (understood as philosophy of freedom), but also seeks to draw attention to its impure part, namely the "empirical man" and the "common moral conscience". Thus, while a metaphysics of morals cannot be founded empirically, Kant's position will be that we could at least realize it in this realm, since observed and described, through "the different doctrines of pure practical reason", the conditions under which the "human action of the individual, groups, and species itself" are supported. The full implications of this, however, will not addressed here, but introduced in the order of importance necessary to construct what Kant termed as "a system of freedom similar to a system of nature".

Keywords: Kant. Anthropology. Moral. Nature.

\section{O projeto antropológico kantiano}

O estudo da antropologia elaborada por Kant tem se desenvolvido de forma crescente, pelo menos nos últimos vinte anos. O número de interpretações acerca do lugar que a mesma ocupa ao longo da obra kantiana ainda é motivo de divergência entre os diversos especialistas. Isto se dá pelo fato de Kant nunca haver efetivamente elaborado uma reflexão decididamente sistemática acerca do papel e do estatuto da antropologia enquanto ciência do homem, de modo que, desde escritos pré-críticos (isto é, anteriores ao período que inaugura a filosofia 
crítica, com a publicação da Crítica da razão pura, em 1781), múltiplos sentidos foram dados ao tema. Um dos problemas que alimentam essa insuficiência, portanto, diz respeito às diversas denominações que a antropologia recebe em muitos momentos, sendo apresentada ora como transcendental, empirica, moral, pragmática, fisiológica ou aplicada. ${ }^{2}$ A cada um desses momentos, correspondem textos e discussões especificas, cuja relação parece pouco clara e, por vezes, de difícil precisão.

Contudo, algumas linhas gerais nos ajudam a compreender em que medida a questão antropológica se dá no interior do pensamento de Kant. Na introdução da sua obra Lógica (1800), por exemplo, afirma Kant ser a filosofia "uma ciência das máximas supremas do uso da nossa razão", a qual visa responder quatro perguntas fundamentais: "1) que posso saber? 2) que devo fazer? 3) que me é permitido esperar? 4) que é o homem?". 3 A primeira pergunta, responde a metafísica; à segunda, a moral; à terceira, a religião; à quarta, a antropologia. No entanto, "tudo isto se poderia incluir na antropologia, visto que as três primeiras questões se referem à última". 4 Nesse sentido, pode-se entender que o filósofo, ao determinar as fontes, os limites e o uso possivel do saber humano, estaria, por analogia, determinando também o que é o homem, ou, se assim quisermos, definindo sua natureza.

Em termos kantianos, portanto, a natureza do homem seria não só racional, mas também sensivel, quer em sentido teórico (tal como na Crítica da razão pura), quer em sentido prático (Fundamentação da metafísica dos costumes e Crítica da razão prática). Disso se conclui que seria a antropologia, preliminarmente, uma ciência da natureza humana, cujo objeto seria nada mais que o homem em sentido transcendental, compreendido como ser racional finito, que pensa e age. Entretanto, uma vez que as condições que amparam o conceito de homem encontrar-se-iam assentadas de modo inteiramente a priori nos textos críticos de Kant, poder-se-ia questionar, afinal de contas, qual a importância da antropologia enquanto ciência empírica. Respostas a isso vêm provocando inúmeros desacordos entre os comentadores, dentre os quais destacam-se posições tanto favoráveis quanto contrárias à tese que aponta a particular relevância da antropologia para o pensamento kantiano - em especial, das relações entre esta e a filosofia moral.

\footnotetext{
Perez (2018, p. 58). Segundo Claudia Schmidt (2007, p. 157), "durante seu período crítico, Kant desenvolveu quatro projetos antropológicos distintos, mas inter-relacionados, que eu chamo de antropologia transcendental, empírica, pragmática e moral". A antropologia transcendental caracterizaria "o autoconhecimento da cognição humana [...]. embora ele [Kant] não explique essa expressão ou a use em seus trabalhos publicados" (SCHMIDT, 2007, p. 159), tendo sido encontrada apenas em uma de suas anotações, datada por volta de 1776-1778 (cf. SCHMIDT, 2007, p. 158). Schmidt, porém, utiliza a expressão "antropologia transcendental" (2007, p. 159) a fim de designar a "descrição dos principios a priori da racionalidade na medida em que estes pertencem a um sujeito especificamente humano" (2007, p. 159-160). Sobre a antropologia empírica, "embora Kant ocasionalmente se refira [a ela] [...] em seus escritos filosóficos críticos, seu mais completo estudo empírico da natureza humana aparece na Antropologia de um ponto de vista pragmático. Aspectos importantes de sua antropologia empírica também são desenvolvidos em suas palestras sobre educação [...] e em vários trabalhos mais curtos de seu periodo crítico" (SCHMIDT, 2007, p. 167). Nesse sentido, antropologia empirica e antropologia pragmática teriam uma origem textual comum (cf. SCHMIDT, 2007, p. 173). No que se refere à antropologia moral, "Kant não dedicou la ela] nenhum de seus escritos" (SCHMIDT, 2007 , p. 176). No entanto, "ele examina vários aspectos da antropologia moral, embora não por este nome, [...] em sua segunda Crítica [...] e em sua Metafísica dos costumes. Ele também discute a educação moral na Pedagogia; e o progresso moral da espécie humana em vários escritos de seu periodo crítico" (SCHMIDT, 2007, p. 176-177). A antropologia fisiológica, por sua vez, seria identificada como uma "disciplina biológica" e não faria propriamente parte do projeto kantiano: "em vez disso, ele está preocupado [...] com a antropologia pragmática; ou o conhecimento da natureza humana decorrente da observação social, uma vez que esta é a parte da antropologia que é pragmaticamente útil" (SCHMIDT, 2007, p. 168). Sobre o conceito de antropologia aplicada, ver Firla (1981): "Firla distingue entre antropologia empírica, transcendental e aplicada nos escritos de Kant e mostra como estas podem estar relacionadas aos diferentes aspectos de sua filosofia moral" (SCHMIDT, 2007, p. 156).

3 Log (AA 09: 25: 13). Citaremos as obras de Kant (salvo quando indicado) tomando por base a edição da Academia e seguindo as abreviaturas sugeridas pela Kant-Forschungsstelle der Johannes Gutenberg-Universität Mainz, sendo AA (Akademie-Ausgabe; edição da Academia das obras coletadas de Kant); Anth (Antropologia de um ponto de vista pragmático - AA 07); GMS (Fundamentação da metafísica dos costumes - AA 04); KpV (Crítica da razão prática - AA 05); KrV (Crítica da razão pura); KU (Crítica da faculdade de julgar - AA 05); Log (Lógica - AA 09); MS (Metafísica dos costumes - AA 06); TP (Sobre a expressão corrente: isto pode ser correto na teoria, mas nada vale na prática - AA 08); V-Anth/Fried (Lições de Antropologia "Friedländer", ministradas no semestre de inverno de 1775/1776 - AA 25); V-Anth/ Mensch (Lições de Antropologia "Menschenkunde", ministradas no semestre de inverno de 1781/1782 - AA 25); V-Mo/Collins (Lições de ética - AA 27); VVRM (Das diferentes raças humanas - AA 02). Além das abreviaturas, volume e página, também indicaremos a paginação referente à tradução utilizada em cada obra. Exemplo: (KpV, AA 05: 20; 35) ICrítica da razão prática, volume cinco da Academia, página vinte (Academia), página trinta e cinco (tradução)]. Na Crítica da razão pura, A e B indicarão se primeira (1781) ou segunda (1787) edição do original, respectivamente. Exemplo: (KrV, A 182) [Crítica da razão pura, página 182 da primeira edição de 1781].
}

$4 \log (A A$ og: 25; 13) 
Vale lembrar que a antropologia surge na forma de lições ministradas por Kant na Universidade de Königsberg desde 1772, estendendo-se até sua aposentadoria em 1796.5 Devido a isso - junto ao fato de que boa parte dos acessos a esses cursos existem na forma de anotações de alunos e do próprio Kant, além de correspondências pessoais - torna-se dificil compreender o que verdadeiramente seria (e se haveria) um tal projeto antropológico, bem como sua conexão com o sistema da crítica. Brandt, por exemplo, busca identificar se, na antropologia de Kant, haveria uma tentativa de resposta ao que fora empreendido por Hume em seu Tratado da natureza humana (1738) - este entendido como programa "de destruição da filosofia especulativa ou racionalista"6 e tentativa de substituição desta pela "science of man Iciência do homem]"7, a qual, baseada na experiência e na observação, forneceria "a única base sólida das outras ciências". ${ }^{8}$ No entanto, para Brandt, "Kant não parece ter falado de sua antropologia pragmática como disciplina filosófica", mas como "enciclopédia da filosofia kantiana em um nível empírico", isto é, um saber enciclopédico que "não está integrado [...] ao sistema da filosofia transcendental ou filosofia crítica".9

Assim, a ideia principal e unificadora do trabalho antropológico de Kant seria a de determinar e caracterizar o ser humano a partir da dimensão empírica, tomando de empréstimo as estruturas e especificações universais que compõem o a priori do homem. Nesse sentido, "a antropologia pragmática e o livro no qual ela encontra sua representação [Antropologia de um ponto de vista pragmático, 1798] não formam um sistema sob uma ideia racional; é apenas uma ciência empírica sistemática". ${ }^{10}$ Por esse motivo, não faria parte do rol da filosofia crítica ou transcendental, uma vez que não pretende fundamentar ou justificar conceitos puros com base na razão, mas servir de "instrução acadêmica útil", "que eu posso chamar de exercício preliminar [Vorübung] no conhecimento do mundo".11 Desse modo, encontraríamos na antropologia um conhecimento pragmaticamente utilizável do homem, isto é, capaz de "dar às pessoas uma orientação na prática, lidando com outras pessoas, mas também consigo mesmas".12

Partindo disso, autores como Patrick Frierson chegam a sustentar a ideia de que a antropologia de Kant teria por tarefa apresentar as condições e obstáculos empíricos que favoreceriam ou impediriam a aquisição de uma boa vontade, de maneira que seu alcance seria "ao mesmo tempo empírica e moralmente relevante". ${ }^{13}$ No entanto, conforme Frierson adverte, "uma das dificuldades em oferecer uma análise da antropologia de Kant é que ainda há discordância sobre onde essa antropologia deve ser encontrada". ${ }^{4}$ Segundo ele, muito embora a Antropologia de um ponto de vista pragmático, bem como as preleções de antropologia ministradas desde a década de 1970, devam ser consideradas antropologia

\footnotetext{
5 Borges (2018a, p. 9). Os Cursos de antropologia (Vorlesungen über Anthropologie), porém, só foram publicados em 1997 no volume 25 das obras completas de Kant, sob a edição de Reinhard Brandt e Werner Stark; o que, por si só, justifica parte da redescoberta desses escritos nos últimos anos. Para Borges (2018a, p. 9), "alguns exemplos desse interesse são os livros de Marcia Baron, Kantian Ethics almost without Apology (1995); Felicitas Munzel, Kant's Conception of Moral Character (1999) e de Allen Wood, Kant's Ethical Thought (1999)". Especialmente no Brasil, destacamos não apenas as contribuições de Borges (2003a, 2003b, 2012, 2017, 2018b), mas também as de Alexandre Hahn (2006a, 2006b, 2010, 2017); Cinara Nahra (2018); Clélia Aparecida Martins (2004, 2018), também tradutora da Antropologia de um ponto de vista pragmático para o português (Iluminuras, 2006); Daniel Omar Perez (2009, 2010a, 2010b, 2012, 2013a, 2013b, 2017a, 2017b. 2018); Joel Thiago Klein (2008, 2012, 2013a, 2013b, 2014, 2016, 2017b, 2017c, 2018); Juan Adolfo Bonaccini (2010); Reginaldo Oliveira Silva (2016); Zeljko Loparic (2003a; 2003b; 2005; 2006; 2007; 2008a; 2008b), além da vastíssima obra do professor e filósofo português Leonel Ribeiro dos Santos, cujos trabalhos (artigos, livros, traduções, cursos e preleções, muitos deles publicados e ministrados em solo brasileiro) abarcam praticamente todos os periodos do pensamento de Kant, incluindo diversos comentários sobre a matriz antropológica deste (a relação completa está disponivel em: https://sites.google.com/site/Lrs1947/. Acesso em: 24 maio 2020).

6 Brandt (1999, p. 7)

Brandt (1999, p. 7)

Brandt (1999, p. 7)

Brandt (1999, p. 8).

Brandt (1999, p. 9)

11 VVRM (AA 02: 443; 23). Apesar disso, a antropologia, para Kant, não deve ser meramente útil à escola, "mas também para a vida" (AA 02: 443; 23), estando, portanto, dividida entre escolástica (ou fisiológica) e pragmática (cf. LOUDEN, 2002, p. 31-32).

12 Brandt (1999, p. 10).

13 Frierson (2003, p. 32)

14 Frierson (2003, p. 32).
} 
para Kant, discordâncias subsistem a respeito da relação dessa antropologia "com a antropologia moral referida na Fundamentação [1785] e na Metafísica dos costumes [1797]". ${ }^{15}$ Em função disso, trabalhos como A religião nos limites da simples razão (1793), partes da Critica da faculdade de julgar (1790) e "muitos dos ensaios mais curtos de Kant, especialmente aqueles que lidam com a história", ${ }^{16}$ seriam, para alguns intérpretes, textos de conteúdo claramente antropológico, uma vez que lidariam, sobretudo se considerarmos os resultados da Crítica da razão prática (1788), com questões que envolvem a relação entre liberdade e natureza humana. Disso resultaria que, para além dos trabalhos explicitamente antropológicos (Antropologia de um ponto de vista pragmático e preleções), haveria uma conexão implícita entre esses e os demais escritos de Kant, a qual poderia ser buscada desde idos da década de 1760.

Segundo Perez, textos como Ensaio sobre as doenças mentais e Observações sobre o sentimento do belo e do sublime (ambos de 1764) se "referem a uma natureza humana tomada observacionalmente e elaborada de modo a classificar diferentes tipos de doença e de apreciação estética". ${ }^{17}$ No primeiro texto, prossegue Perez, "Kant vincula as diferentes loucuras com o próprio corpo humano e seu funcionamento"; no segundo texto, "vincula o belo com a mulher e o sublime com o homem afirmando a relação de fundamento relativo que existiria entre o juizo [estético] e a natureza humana, como o corpo propriamente dito".18 De igual modo, textos como Das diferentes raças humanas (1775) pretenderiam "debater o problema da unidade biológica da espécie humana e da possibilidade de diferentes raças segundo suas caracteristicas estéticas e culturais".19 Todas essas discussões integrariam a primeira parte da antropologia de Kant, denominada por ele de antropologia fisiológica.

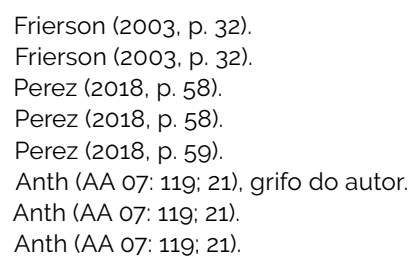

Conforme a Antropologia de um ponto de vista pragmático, "uma doutrina do conhecimento do ser humano sistematicamente composta (antropologia) pode ser tal do ponto de vista fisiológico ou pragmático". 20 De um lado, o conhecimento fisiológico trataria de "investigar o que a natureza faz do homem"21; de outro, "o pragmático, o que ele faz de si mesmo, ou pode e deve fazer como ser que age livremente".22 O termo pragmático surgiria ainda na década de 1970, a fim de designar esse segundo campo da antropologia e distingui-lo da investigação meramente psicológica do homem. No curso de Friedländer (1775-76), essa distinção pode ser vista com bastante clareza. Cito aqui na íntegra:

O homem nos interessa, portanto, mais que a natureza, pois a natureza existe em função do homem, o homem é o fim da natureza. Diz-se que o homem conhece o mundo, se viajou e o viu. Isso, entretanto, ainda não é conhecimento do mundo; conhece o mundo aquele que conhece o homem. O conhecimento do homem, no entanto, pode ser de duas espécies. 1. O comportamento ou procedimento casual dos homens, ou o estado. 2. A natureza da humanidade. A antropologia, contudo, não é uma antropologia local, mas antropologia geral. Nela não se toma conhecimento do estado dos homens, mas da natureza da humanidade, pois a indole local dos homens sempre se modifica, mas a natureza da humanidade não. Antropologia é, pois, conhecimento pragmático daquilo que flui de sua natureza, não conhecimento físico ou geográfico, pois estes se vinculam a tempo e lugar, e não são constantes. Quem viajou e conheceu muitos homens, aprendeu a situação e as modas das cidades mais famosas, dele não se pode, todavia, dizer que conheceu o homem, pois tomou conhecimento apenas da situação, que é bastante mutável, mas se conheço a humanidade, ela deve convir a todas as espécies de homem. Antropologia não é, pois, descrição do homem, mas da natureza dos homens. Consideramos, portanto, o conhecimento do homem com respeito a sua natureza. O conhecimento da humanidade é, ao mesmo tempo, conhecimento de mim. No fundamento tem, pois, de estar um conhecimento natural, de acordo com o qual podemos julgar aquilo que está no fundamento de cada homem; então teremos princípios seguros pelos quais poderemos proceder. Por isso, temos de estudar a 
nós mesmos, e porque queremos aplicá-lo a outros, não devemos estudar a humanidade de maneira psicológica ou especulativa, mas pragmática, pois todos os ensinamentos pragmáticos são ensinamentos de prudência, onde também dispomos dos meios de fazer um uso adequado de todas as nossas habilidades, pois estudamos o homem para nos tornarmos mais prudentes, prudência esta que se torna ciência. Não precisamos, pois, viajar para conhecer o homem, mas podemos avaliar sua natureza em qualquer lugar. Mas é preciso estudar o homem, o sujeito, se também é capaz de executar aquilo que se exige que faça: a causa por que a moral e os sermões, nos quais jamais se cansa de fazer exortações, têm pouco efeito, é a falta de conhecimento do homem. A moral tem de estar vinculada ao conhecimento da humanidade. ${ }^{23}$

Como se vê, embora a antropologia tenha pressuposto em seu fundamento um conhecimento especulativo do homem (isto é, psicológico ou fisiológico), seu estudo teria por objeto principal o próprio homem tomado em sentido pragmático, em uma dimensão que compreenderia tanto a esfera prudencial quanto a esfera moral. A esfera prudencial seria o conhecimento da natureza humana em relação ao seu comportamento ou procedimento casual, por meio do qual seria possivel observar o uso que faz de suas habilidades no trato com outros homens. Diz Kant que a "habilidade está direcionada para coisas, a prudência, para seres humanos. 0 relojoeiro é hábil se faz um relógio perfeito; mas se sabe fazê-lo chegar rapidamente ao homem, ao fazê-lo bem segundo a moda, ele é prudente".24

Isso se aproxima da questão moral à medida que o conhecimento da natureza do homem (isto é, da "maneira como emprega seus conhecimentos segundo regras de prudência"25) passa a examinar se esse mesmo homem "também é capaz de executar aquilo que se exige que faça". ${ }^{26}$ Nesse sentido, a aplicação bem-sucedida da moralidade estaria condicionada, em certa medida, ao grau de desenvolvimento pragmático do homem em relação às suas disposições e habilidades técnicas, capacidade essa que pode ser observada e avaliada por meio da antropologia. Assim, ao passo que a produção de um relógio da moda estaria desvinculada de qualquer questão ou decisão moral, outros exemplos poderiam suscitar o inverso. Conforme Joel Klein sugere:

\begin{abstract}
Tome-se por exemplo um individuo que está pescando em sua canoa e vê a uma certa distância um acidente de barco. Ele tenta ir em direção ao sinistro, mas lhe falta a habilidade de remar com rapidez e constância, assim como a habilidade de nado. Além disso, o indivíduo não levou consigo seu celular, o que seria prudente para alguma eventualidade e para chamar ajuda. Ou seja, o individuo na medida em que tenta realizar o salvamento, está agindo moralmente, mas por lhe faltar o desenvolvimento de certas disposições técnicas e pragmáticas, seu agir provavelmente não seria bem-sucedido. ${ }^{27}$
\end{abstract}

Desse modo, embora tais disposições, tomadas isoladamente, não tenham em si qualquer conotação ou valor moral, algo diferente acontece à medida que ambos os conhecimentos (a habilidade e a prudência) passam a ser vinculados a uma ação moralmente observável. Usando de um exemplo do próprio Kant, poderiamos, pois, afirmar: "não se abandonam vícios porque são contra a moral, mas porque são bem grosseiros".28 Entretanto, à medida que os vícios redundariam "em grande rudeza, e não haveria nenhum esforço para se portar bem exteriormente", ${ }^{29}$ a tentativa de evitá-los mostrar-se-ia favorável à moralidade.

Com base nisso, torna-se possivel compreender em que medida os deveres morais teriam por referência o conhecimento da natureza humana, observada empiricamente. Na Fundamentação da metafísica dos costumes, muitos são os casos em que isso se dá. Vejamos, especificamente, a primeira seção. Lá, Kant elenca quatro deveres fundamentais. O primeiro deles diz respeito à conservação da vida. Com efeito:

[...] conservar cada qual a sua vida é um dever, e é além disso uma coisa para que toda a gente tem inclinação imediata. Mas por isso mesmo é que o cuidado, por vezes ansioso, que a maioria

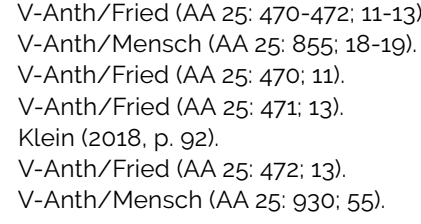


dos homens the dedica não tem nenhum valor intrinseco e a máxima que o exprime [não tem] nenhum conteúdo moral. Os homens conservam a sua vida conforme ao dever, sem dúvida, mas não por dever. Em contraposição, quando as contrariedades e o desgosto sem esperança roubaram totalmente o gosto de viver; quando o infeliz, com fortaleza de alma, mais enfadado do que desalentado ou abatido, deseja a morte, e conserva, contudo, a vida sem a amar, não por inclinação ou medo, mas por dever, então a sua máxima tem um conteúdo moral. ${ }^{30}$

Aqui, Kant examina a conservação da vida sob duas perspectivas ou graus. Em primeiro lugar, definindo em que medida essa conservação não exprimiria nenhum conteúdo moral, mas apenas uma inclinação imediata, e que corresponderia à prudência privada, isto é, "a sagacidade em reunir [...] intenções para alcançar uma vantagem pessoal durável" - nesse caso, "o maior bem-estar próprio". ${ }^{11}$ Em um segundo momento, definindo como moral a máxima que orienta a conservação independentemente de motivos sensiveis.

Diferentemente dos cursos de antropologia da década de 1770 , onde a prudência do relojoeiro fora tratada "nas relações com o mundo", 32 o conceito de prudência ganha aqui novas significações e passa também a remeter à conduta interna do homem. Assim, a conservação da vida enquanto inclinação imediata estaria vinculada ao uso da prudência exatamente pelo fato da inclinação encontrar-se enraizada às sensações e àquilo que o homem enquanto ser livre faz delas segundo princípios. Diante disso, o ato de conservar-se só seria considerado moral caso os móbiles da sensibilidade não exercessem qualquer influência sobre a vontade do homem e os princípios determinantes da ação fossem tão somente os "mandamentos (leis) da moralidade".33 Em outras palavras, um ser humano que conserva a própria vida só estaria agindo moralmente caso não estivesse buscando tão-somente bem-estar próprio; o que, por conseguinte, só poderia ser observado caso levássemos em conta a natureza empírica desse mesmo ser, bem como seu grau de influência face à determinação das máximas.

O mesmo ocorre nos demais exemplos:

Ser caritativo quando se pode sê-lo é um dever. e há além disso muitas almas de disposição tão compassiva que, mesmo sem nenhum outro motivo de vaidade ou interesse, acham intimo prazer em espalhar alegria à sua volta $e$ se podem alegrar com o contentamento dos outros, enquanto este é obra sua. Eu afirmo, porém, que neste caso uma tal ação, por ser conforme ao dever, por amável que ela seja, não tem contudo nenhum verdadeiro valor moral. mas vai emparelhar com outras inclinações, por exemplo o amor das honras que, quando por feliz acaso topa aquilo que efetivamente é de interesse geral e conforme ao dever, é consequentemente honroso e merece louvor e estímulo, mas não estima; pois à sua máxima falta o conteúdo moral que manda que tais ações se pratiquem, não por inclinação, mas por dever. Admitindo pois que o ânimo desse filantropo estivesse velado pelo desgosto pessoal que apaga toda a compaixão pela sorte alheia, e que ele continuasse a ter a possibilidade de fazer bem aos desgraçados, mas que a desgraça alheia não o tocava porque estava bastante ocupado com a sua própria; se agora, que nenhuma inclinação o estimula já, ele se arrancasse a esta mortal insensibilidade e praticasse a ação sem qualquer inclinação, simplesmente por dever, só então é que ela teria o seu autêntico valor moral. Mais ainda: - Se a natureza tivesse posto no coração deste ou daquele homem pouca simpatia, se ele (homem honrado de resto) fosse por temperamento frio e indiferente às dores dos outros por ser ele mesmo dotado especialmente de paciência e capacidade de resistência às suas próprias dores e por isso pressupor e exigir as mesmas qualidades dos outros; se a natureza não tivesse feito de um tal homem (que em boa verdade não seria o seu pior produto) propriamente um filantropo, - não poderia ele encontrar ainda dentro de si um manancial que the pudesse dar um valor muito mais elevado do que o dum temperamento bondoso? Sem dúvida! - e exatamente ai é que começa o valor do caráter. que é moralmente sem qualquer comparação o mais alto, e que consiste em fazer o bem, não por inclinação, mas por dever

Assegurar cada qual a sua própria felicidade é um dever (pelo menos indiretamente); pois a ausência de contentamento com o seu próprio estado num torvelinho de muitos cuidados e no meio de necessidades insatisfeitas poderia facilmente tornar-se numa grande tentação para transgressão dos deveres. Mas, também sem considerar aqui o dever, todos os homens têm já por si mesmos a mais forte e intima inclinação para a felicidade, porque é exatamente nesta ideia que se reúnem numa soma todas as 
inclinações. Mas o que prescreve a felicidade é geralmente constituido de tal maneira que vai causar grande dano a algumas inclinações, de forma que o homem não pode fazer ideia precisa e segura da soma de satisfação de todas elas a que chama felicidade; por isso não é de admirar que uma única inclinação determinada, em vista daquilo que promete e do tempo em que se pode alcançar a sua satisfação, possa sobrepor-se a uma ideia tão vacilante. Assim um homem, por exemplo um gotoso, pode escolher o regalo que the dá qualquer comida de que gosta e sofrer quanto pode, porque, pelo menos segundo o seu cálculo, não quis renunciar ao prazer do momento presente em favor da esperança talvez infundada da felicidade que possa haver na saúde. Mas também neste caso, mesmo que a inclinação universal para a felicidade não determinasse a sua vontade, mesmo que a saúde, pelo menos para ele, não entrasse tão necessariamente no cálculo, ainda aqui, como em todos os outros casos, continua a existir uma lei que the prescreve a promoção da sua felicidade, não por inclinação, mas por dever - e é somente então que o seu comportamento tem propriamente valor moral.

E sem dúvida também assim que se devem entender os passos da Escritura em que se ordena que amemos o próximo, mesmo o nosso inimigo. Pois que o amor enquanto inclinação não pode ser ordenado, mas o bem-fazer por dever, mesmo que a isso não sejamos levados por nenhuma inclinação e até se oponha a ele uma aversão natural e invencivel, é amor prático e não patológico, que reside na vontade e não na tendência da sensibilidade, em princípios de ação e não em compaixão lânguida. E só esse amor é que pode ser ordenado. ${ }^{34}$

Analisando a dinâmica dos três argumentos, facilmente se percebe a presença de um conteúdo empirico preexistente, ante o qual a reflexão moral é construída. Essa relação se dá por um motivo já aduzido: o fato da vontade humana não ser inteiramente racional e, com isso, encontrar-se frequentemente diante de uma encruzilhada, na qual se vê constantemente obrigada a escolher "entre o seu princípio a priori, que é formal, e o seu móbil a posteriori, que é material".35 Assim, embora o princípio supremo da moralidade não possa ser derivado da particular constituição da natureza humana, seria esta "nobre o bastante para fazer de uma ideia tão respeitável a sua regra de conduta [ainda que] fraca demais para
Lhe obedecer".36 Em outras palavras, caberia à natureza humana aplicar a lei como regra, uma vez observada a sua inerente fraqueza frente ao apelo das inclinações sensiveis.

A relação de complementaridade entre prudência e moral surge, porém, ao observarmos que, no caso dos deveres acima citados, o cumprimento da moralidade dependeria, em um certo sentido, do desenvolvimento dessas disposições imediatas, não com vistas ao simples bem-estar, mas tendo a moral como finalidade. Nesse ponto, é digno de nota aquilo que diz Kant ao início da primeira seção:

Algumas qualidades são mesmo favoráveis à
[...] boa vontade e podem facilitar muito a sua
obra, mas não têm, todavia, nenhum valor intimo
absoluto, pelo contrário pressupõem ainda e
sempre uma boa vontade, a qual restringe a alta
estima que, aliás com razão, por elas se nutre,
e não permite que as consideremos absoluta-
mente boas. Moderação nas emoções e paixões,
autodominio e calma reflexão são não somente
boas a muitos respeitos, mas parecem constituir
até parte do valor intimo da pessoa; mas falta
ainda muito para as podermos declarar boas
sem reserva (ainda que os antigos as louvassem
incondicionalmente). Com efeito, sem os princi-
pios duma boa vontade, podem elas tornar-se
muitissimo más, e o sangue-frio dum facinora
não só o torna muito mais perigoso como o faz
também imediatamente mais abominável ainda
a nossos olhos do que o julgariamos sem isso. ${ }^{37}$

Dito isso, temos que, embora algumas qualidades sejam favoráveis à moralidade, nenhuma delas possui valor intimo, mas apenas condicional, uma vez que dependem dos princípios duma boa vontade para que não se tornem muitíssimo más. Assim, a moderação nas paixões poderia tanto servir a fins morais, se orientada pela boa vontade, por exemplo, quanto tornar um facinora de sangue-frio ainda mais perigoso. No caso da conservação da vida, da caridade, da busca pela felicidade e do amor ao próximo, Kant os toma como deveres à medida que reconhece nessas disposições naturais um obstáculo inevitável, e que, não podendo ser retiradas da natureza humana, devem poder ser 
orientadas segundo os mandamentos da razão. ${ }^{38}$

Não à toa, diz Kant nas Lições de ética (1784-85),39 ao tratar da perfeição moral como destino final do gênero humano, não haver outro caminho para tal fim a não ser pela educação: "esta deve ser acomodada a todos os fins da natureza, da sociedade civil e da vida doméstica". ${ }^{\circ 0}$ Entretanto, adverte:

[...] nossa educação em casa e nas escolas ainda é muito defeituosa, não só em relação à disciplina, à doutrina e ao cultivo do talento, mas também em relação à formação do caráter de acordo com principios morais. Estamos mais preocupados com a habilidade do que com a disposição de fazer bom uso dela. ${ }^{41}$

Até agora, portanto, estaria a educação voltada apenas para o uso da habilidade, de modo que a boa disposição, ligada à formação do caráter de acordo com princípios morais, fora completamente desconsiderada. Isso, porém, não apenas obstaria ao gênero humano o alcance da maior perfeição moral, mas mesmo impediria que os governantes pudessem ser educados, de modo a garantir que o Estado - e, por conseguinte, toda a opinião pública - viesse a ser beneficiado por essa forma de ensino. ${ }^{42}$ Logo, caberia à educação adquirir uma finalidade moral, capaz de orientar o uso das habilidades (mediante prudência) segundo princípios da razão. O conhecimento da natureza humana, com efeito, ajudaria nessa demanda, uma vez que permitiria observar em que medida deveria o homem ser educado. Desse modo, o progresso moral da humanidade deveria se dar segundo uma mediação pedagógica e institucional, ${ }^{43}$ sendo esse, em última instância, o resultado final almejado pela antropologia pragmática "em relação à destinação do ser humano eà caracteristica do seu aprimoramento".44 Isto porque:

O ser humano está destinado, por sua razão, a estar numa sociedade com seres humanos e a se cultivar, civilizar e moralizar nela por meio das artes e das ciências, e por maior que possa ser sua propensão animal a se abandonar passivamente aos atrativos da comodidade e do bem-estar. que ele denomina felicidade, ele está destinado a se tornar ativamente digno da humanidade na luta com os obstáculos que a rudeza de sua natureza coloca para ele. O ser humano tem, pois, de ser educado para o bem [.... ${ }^{45}$

38 Conforme Paton (1946, p. 23), "estritamente falando, a Fundamentação da Metafísica dos Costumes e a Critica da Razão Prática pertencem à ética pura, embora possam ocasionalmente trazer problemas de ética aplicada a título de ilustração". Segundo Perez (2018, p. 68), Kant exige, na Fundamentação, "a não inclusão de quaisquer elementos empíricos, antropológicos, para o desenvolvimento do seu trabalho. Porém, os traços desses conhecimentos antropológicos se deixam ver no próprio texto". Assim, "[...] embora os princípios da moralidade não se devam buscar na natureza humana, é bem claro no texto que é a ela que se aplica, portanto seria razoável pensar que haveria algum tipo de vínculo a ser considerado" (PEREZ, 2018, p. 68). Wood (1999, p. 193-194), com efeito, considera que, mesmo na Fundamentação, Kant "não pode abstrair inteiramente da antropologia empírica. Suas ilustrações do principio moral dependem de suposições substantivas sobre a natureza humana - [ilustrações estas] sobre o propósito natural do amor-próprio e dos talentos naturais, sobre nossa dependência da ajuda beneficente de outros seres humanos, e sobre as prováveis consequências para a prática de prometer caso se tornasse uma lei da natureza que aqueles que precisassem de dinheiro tomassem empréstimos sem intenção de cumprir suas promessas de pagamento. Mas não há tentativa de mostrar como esse conhecimento está relacionado a um estudo sistemático da natureza humana. Talvez seja por isso que muitos leitores, apesar das declarações explícitas de Kant em contrário, pensam que, para ele. a filosofia moral como um todo não contém tal estudo e não precisa de um".

39 Assim como as lições de antropologia, as Lições de ética formam um conjunto de notas redigidas por alunos do próprio Kant desde a década de 1770, tendo sido utilizada na edição da academia (editada por Gerhard Lehmann em 1974) o manuscrito de Georg Ludwig Collins, "um caderno de 606 páginas repleto de notas marginais, pertencente a um estudante de teologia matriculado em outubro de 1784" (CUNHA; FELDHAUS, 2018, p. 18), que aqui citamos a partir da tradução inglesa de Peter Heath (Cambridge University Press, 1997). As traduções para o português são de nossa inteira responsabilidade.

$40 \quad \mathrm{~V}$-Mo/Collins (AA 27: 471: 221), tradução nossa.

$41 \quad$-Mo/Collins (AA 27: 471; 221), tradução nossa.

"[...] se a educação fosse ordenada de tal modo que os talentos fossem bem desenvolvidos e o caráter fosse formado de maneira moral, então ela ascenderia ao trono e os príncipes seriam depois educados por pessoas que tivessem apenas essas habilidades. Até agora, contudo, nenhum único governante contribuiu em nada para a perfeição da humanidade, para a felicidade interna ou para o valor da humanidade; eles apenas procuraram a prosperidade de seus dominios, o que para eles é a principal preocupação. Mas, depois de uma tal educação, sua mente se ampliaria de tal maneira a exercer influência sobre a concórdia e a conciliação. E uma vez que os princípios [dessa educação] já tivessem surgido, eles adquiririam permanência e, logo que comumente difundidos, manter-se-iam através da opinião pública. Mas o monarca sozinho não pode ser treinado dessa maneira; todos os membros do Estado devem ser educados da mesma forma, e então o Estado teria a estabilidade necessária" (V-Mo/Collins, AA 27: 471; 221-222).

43 "Essa construção histórica ocorre de uma forma coletiva que não é mediada biologicamente, mas pedagógica e institucionalmente. Se se tratasse de um caráter [moral] que pudesse ser transmitido de forma biológica (geneticamente), então estar-se-ia afirmando que as gerações futuras herdariam os caracteres desenvolvidos racionalmente pela geração anterior, por conseguinte, que novas gerações já poderiam nascer como seres mais educados e mais morais. Ora, segundo Kant, essa especulação dependeria de uma ampliação do fundamento moral do gênero humano, para o que 'exigir-se-ia uma espécie de nova criação (influxo sobrenatural)'" (KLEIN, 2018, p. 104-105).

44 Anth (AA 07: 324; 219), grifo do autor.

45 Anth (AA 07: 324-325; 219), grifo do autor. 
Tendo isso em vista, torna-se nítida não apenas uma relação de parentesco entre a Fundamentação e a Antropologia de um ponto de vista pragmático, mas mesmo um vínculo entre esta e aquilo que, no texto de 1785, fora chamado de antropologia prática, isto é, a parte empírica da ética. Nas palavras de Kant: "toda a moral [...] para a sua aplicação aos homens precisa da Antropologia". ${ }^{66} \mathrm{O}$ vínculo, por sua vez, também se estende a textos tardios como a Metafísica dos costumes (1797), porém sob o nome de antropologia moral. ${ }^{47}$ Essa é uma posição que associa-se diretamente com a de Robert Louden, o qual vê na antropologia kantiana o desenvolvimento de uma segunda parte da ética, chamada por ele de ética impura, e que se articula com as diversas doutrinas da razão prática - a saber: arte, religião, história e pedagogia no sentido de aplicar, segundo princípios, os resultados obtidos pela filosofia moral pura.

Entretanto, compreende Louden não ser a antropologia moral (ou prática) idêntica à antropologia pragmática, mas, antes, "uma sub-disciplina de um mais amplo campo, que é a antropologia pragmática", ${ }^{48}$ assim como a antropologia fisiológica, a qual precede o conhecimento pragmático do homem, ao mesmo tempo em que the serve de fundamento. Nesse sentido, seria a antropologia moral uma dimensão crucial da ética kantiana, cujas partes poderiam ser encontradas não apenas na Antropologia de um ponto de vista pragmático ou nas preleções dedicadas a esta, como já frisado, mas também nos cursos sobre educação, nos escritos sobre história, bem como em partes de obras dedicadas à estética e à religião. ${ }^{49}$ Assim, ainda que houvesse, do ponto de vista teórico, um "abismo intransponivel" entre o domínio sensivel e o domínio suprassensivel, "este deve[ria], no entanto, ter influência sobre o primeiro, ou seja, o conceito da liberdade deve[ria] tornar efetivo, no mundo sensivel, o fim fornecido por suas leis", 50 a saber: "realizar o aperfeiçoamento do ser humano mediante cultura progressiva".51 Logo, embora as leis morais não derivassem da sensibilidade, mas tão-somente da razão prática, torná-las "consistentes com os fatos da vida humana", a partir do conhecimento do homem (e seu respectivo desenvolvimento), seria a principal (e gigantesca) tarefa da ética impura..$^{52}$ Isto porque,

46 GMS (AA 04: 412; 46).

47 "Assim como em uma metafísica da natureza [...] devem existir principios para a aplicação daqueles princípios universais supremos de uma natureza em geral aos objetos da experiência, também uma metafísica dos costumes não pode deixar de tê-los, e precisaremos tomar frequentemente como objeto a natureza particular do homem, cognoscivel apenas pela experiência, para nela mostrar as conclusões dos principios morais universais sem por meio disso tirar algo da pureza dos últimos, nem pôr em dúvida sua origem a priori. - Isso quer dizer apenas que uma metafísica dos costumes não pode estar fundada na antropologia, mas pode ser aplicada a ela. A contraparte de uma metafísica dos costumes, como o outro membro da divisão da filosofia prática em geral, seria a antropologia moral, que conteria as condições subjetivas tanto impeditivas como favorecedoras da realização das leis da primeira na natureza humana: a produção, difusão e consolidação dos principios morais (na educação e no ensino escolar e popular) e, de igual modo, outros ensinos e prescrições fundados na experiência. Desta antropologia não se pode prescindir, mas ela não deve de modo algum preceder aquela metafísica dos costumes ou ser a ela misturada, porque então se corre o perigo de extrair leis morais falsas, ou ao menos indulgentes, que fazem com que pareça inacessivel o que precisamente por isso não é alcançado - ou porque a lei não foi discernida nem apresentada em sua pureza (enquanto aquilo em que consiste também sua força), ou porque são utilizados móbiles totalmente inautênticos ou impuros para o que em si é bom e conforme ao dever, móbiles que de resto não deixam nenhum princípio moral seguro nem como fio condutor do juízo nem como disciplina da mente no cumprimento do dever, cuja prescrição tem de ser dada absolutamente a priori apenas pela razão pura" (MS, AA 06: 217: 23, grifo do autor).

48 Louden (2002, p. 33).

49 Louden (2000, p. 6).

50 KU (AA 05: 175-176; 76)

51 Anth (AA 07: 322; 216), grifo nosso. Conforme Loparic (2003b, p. 24), o Kant tardio resolve, "de uma nova maneira, questões relativas à unidade do sistema da filosofia critica. O problema da compatibilidade entre a natureza e a liberdade, por exemplo, não fica em aberto, como na primeira Crítica, nem permanece confinado aos juizos meramente reflexivos, como ocorre na terceira Crítica, mas recebe uma solução, ao mesmo tempo racional e sensificada, em termos da teoria da exequibilidade física de principios a priori de politica moral". Nesse particular, se considerarmos a relação entre política e moral enquanto objeto que compõe o discurso da antropologia (ou ética impura), concluiremos que o pensamento kantiano tardio consiste, em grande medida, em uma tentativa de solucionar, por meio do estudo das condições empíricas contrárias ou favoráveis à realização dos conceitos morais da razão prática pura, problemas que a filosofia transcendental teve de deixar em aberto nas três primeiras Críticas, dentre elas, o suposto abismo intransponivel entre natureza e liberdade. Por essa razão, tanto a Antropologia de um ponto de vista pragmático quanto a Metafísica dos costumes integrariam parte da saída proposta por Kant pós-1790, a saber: "a moralização da humanidade, a ser realizada ao longo de um progresso para melhor, definido em termos da doutrina do direito (no essencial, pelas ideias de soberania popular e de constituição republicana), assentado em princípios a priori da história do gênero humano e promovido por uma pedagogia a priori" (LOPARIC, 2006, p. 71-72). Para uma reconstrução detaIhada dessa modificação progressiva operada nos textos kantianos, assim como sua relação com a ideia de sumo bem, ver Sipert (2013). 52 Louden (2000, p. 9). 
é um dever para o ser humano esforçar-se "para cada vez mais alçar-se da rudeza de sua natureza, da animalidade (quoad actum), à humanidade, unicamente através da qual ele é capaz de proporse fins; suprir sua ignorância por meio de instrução e corrigir seus erros". 53

Como Louden bem explica, "o dever não é de ser perfeito, mas sim de lutar pela perfeição".54 Uma das preocupações centrais de Kant, desse modo, seria a de tornar os principios morais eficazes na vida humana. O objetivo dessa estratégia seria o de descobrir as dificuldades que envolvem a conduta e, com isso, "pensar muito mais cuidadosamente sobre quando, onde e como introduzir os princípios aos seres humanos", o que, muitas vezes, implicaria na necessidade de "reformas institucionais e sociais". 55 Por esse motivo, a ética impura (ou, melhor dizendo, a antropologia moral) estaria também vinculada ao aspecto político, ${ }^{66}$ haja vista que, conforme as Lições de ética, a formação do caráter humano seria também um papel do Estado; o que, por consequência, envolveria questões de aplicação do direito público na composição da sociedade civil. ${ }^{57}$

Dito isso, não é por acaso que as Lições iniciam com um importante aviso em seu Proêmio: "a moralidade não pode existir sem a antropologia, pois é preciso primeiro saber se o agente também está em condições de realizar o que the é exigido, o que ele deve fazer". ${ }^{8}$ Certamente, é possivel "considerar a filosofia prática mesmo sem a antropologia, ou sem o conhecimento do agente, mas, nesse caso, ela é meramente especulativa, ou uma ideia".59 De fato, "as pessoas estão sempre pregando sobre o que deve ser feito, e ninguém pensa se isso pode ser feito".60 Por essa razão, "é preciso saber do homem se ele também pode fazer o que é exigido dele". ${ }^{61}$ Afinal, "a consideração de regras é inútil se não se pode preparar o homem para segui-las. Portanto, estas duas ciências [filosofia prática e antropologia] estão intimamente ligadas".62

Também não é por acaso que, na Fundamentação, afirme o filósofo de Königsberg ser o conceito de dever, posto "sob certas limitações e obstáculos subjetivos"63, condição indispensável para se desenvolver "o conceito de uma boa vontade altamente estimável em si mesma e sem qualquer intenção ulterior, conceito que reside já no bom senso natural".64 Aqui, a tentativa de "buscar ajuda na filosofia", única capaz de fornecer ao senso comum "informações e instruções claras sobre a fonte do seu principio", ${ }^{65}$ só ganhará significado em decorrência de um primeiro olhar sobre o que se intitula "conhecimento vulgar", que nada mais é do que o campo de aplicação do princípio supremo da moralidade. Nas palavras de Kant, tratar-se-á, pois, de "percorrer analiticamente o caminho do conhecimento vulgar para a determinação do principio supremo desse conhecimento",66 em seguida, "e em sentido inverso, sinteticamente, do exame deste principio e das suas fontes para o conhecimento vulgar onde se encontra a sua aplicação".67

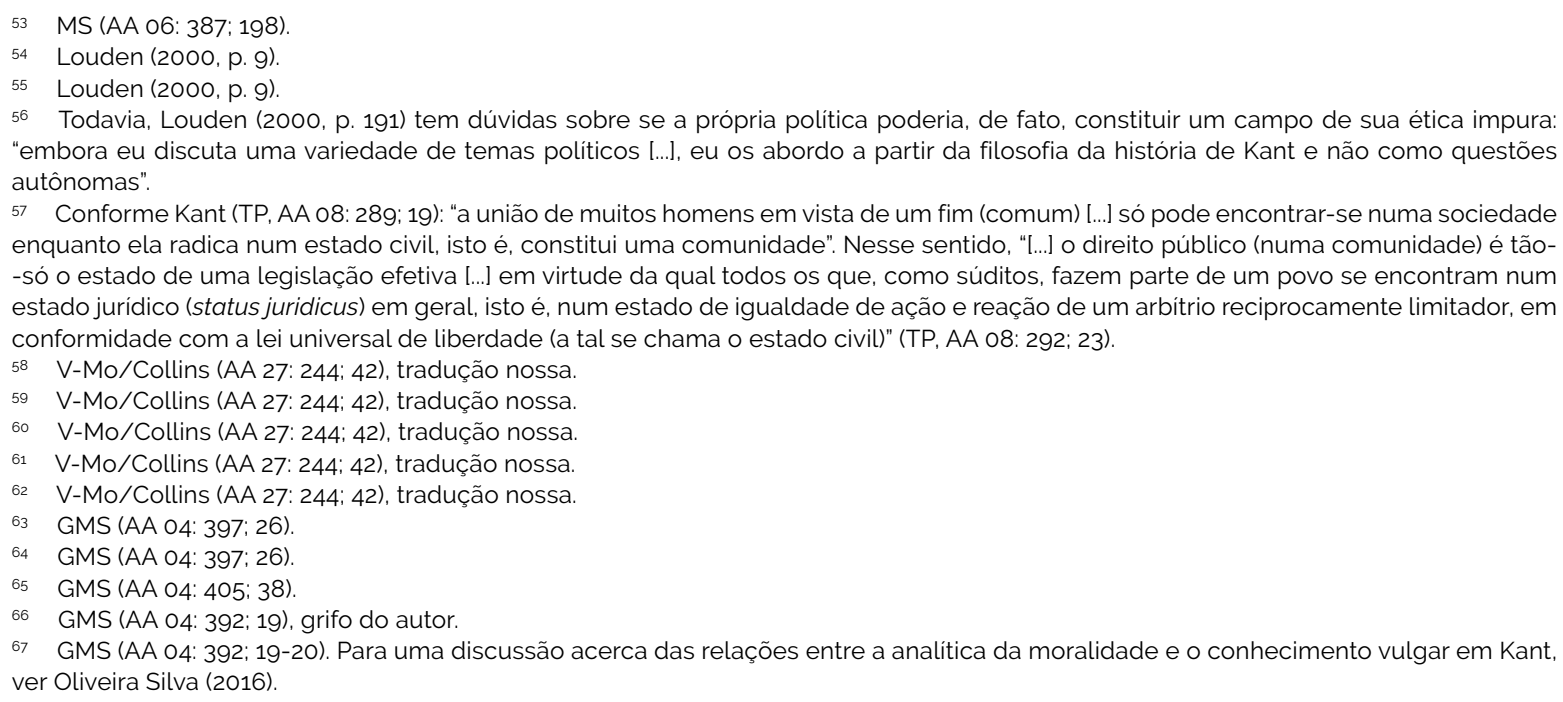




\section{Graus e tipos de aplicação da moral ${ }^{68}$}

Na visão kantiana defendida por Louden, os agentes morais humanos são criaturas "nas quais um componente puro interage com um componente impuro"69. Diante disso, a meta da ética de Kant consistiria precisamente na necessidade de que essa interação fosse "aquela em que o componente puro exercelsse] controle sobre o empírico",70 isto é, um projeto no qual a busca explícita por principios fundamentais não empíricos trouxesse "conteúdo empírico para fins de aplicação à vida humana".71 Aceita essa divisão, vimos, pois, que não apenas a Antropologia de um ponto de vista pragmático comporia a filosofia moral aplicada, mas uma série de textos desde o periodo pré-crítico. Em função desses, viu-se, também, que a antropologia moral (ou ética impura) "não é um conteúdo empírico que deve ser misturado aos principios a priori",72 como se estes dependessem da experiência para serem justificados. Antes, "é somente na aplicação posterior de principios puros às circunstâncias empíricas que os elementos não-puros devem ser introduzidos"73

Vale salientar, portanto, que o termo impuro, proposto por Louden, não é o mesmo que imoral, sujo ou indecente, conforme acepção popular da palavra, mas tão-somente não puro, isto é, "extraído simplesmente da experiência", ou, como se diz, "conhecido [...] apenas a posteriori ou empiricamente".74 Entretanto, "um motivo puro (isto é, não-empírico)"75 deve ser sempre o fundamento determinante da vontade em uma ação que se pretenda moral. O princípio da ação, assim sendo, deve ser "livre de todas as influências de motivos contingentes que só a experiência pode fornecer", ${ }^{6}$ ainda que a aplicação desse princípio ocorra propriamente nesta. Isto porque a ética pura,

[...] embora deva vir primeiro, não nos leva tão longe quanto precisamos ir. Ela pode nos mostrar quais são os princípios fundamentais do pensamento e ação moral para os seres racionais em geral, mas nunca pode nos mostrar [...] o que fazer em uma situação concreta. Principios da ética pura, precisamente porque são puros, não têm nenhuma conexão especial com a vida humana. Tal conexão só pode ser estabelecida trazendo o conhecimento empírico da natureza humana para o quadro. ${ }^{77}$

A afirmação de Louden, apesar de inicialmente estranha, coincide com uma das posições tardias de Kant sobre a ética. Segundo o filósofo de Königsberg, "a possibilidade do conceito de uma coisa (que ele não se contradiga) não é ainda suficiente para se admitir a possibilidade da coisa mesma (a realidade objetiva do conceito)".78 Nesse sentido, posso, a partir do imperativo categórico, fazer com que minha máxima (isto é, o principio subjetivo da minha ação) não contradiga aquilo que o imperativo da moralidade ordena enquanto princípio das ações morais em geral (a saber, que a minha máxima possa se tornar, também, principio de uma legislação universal). No entanto, essa condição é apenas restritiva (negativa) e serve tão-somente para qualificar a minha máxima segundo a sua forma, mas não garante, de modo algum, a sua realização. ${ }^{79}$

Para tanto, far-se-ia necessário "conhecer [...] os meios mais hábeis" para um tal fim, ${ }^{80}$ isto é, saber se eu, enquanto agente moral racional, seria capaz de executar aquilo que me fora exigido; o que, como vimos, constitui-se desde cedo

\footnotetext{
68 A partir daqui, seguiremos com a leitura de Louden (salvo quando indicado), considerando sua proximidade complementar com outras posições da literatura (notadamente WOOD, 1999; FRIERSON, 2003; BONACCINI, 2010; BORGES, 2018b; e, em certa medida, PEREZ, 2018), bem como seu alcance frente à investigação da presença implícita da antropologia em obras não propriamente antropológicas incluindo as da ética pura (cf. PATON, 1946, p. 23).

69 Louden (2000, p. 10).

70 Louden (2000, p. 10).

Louden (2000, p. 11).

Borges (2018b, p. 185)

Louden (2000, p. 10).

$\mathrm{KrV}(\mathrm{A} 2)$.

Louden (2000, p. 10).

GMS (AA 04: 426; 65)

Louden (2000, p. 11)

MS (AA 06: 382; 192).

"As máximas são aqui consideradas como principios subjetivos que meramente se qualificam para uma legislação universal; o que é apenas um princípio negativo (não contradizer uma lei em geral)" (MS, AA 06: 389; 200).

80 MS (AA 06: 389; 201).
} 
em objeto da prudência (e, por conseguinte, da antropologia). Por essa razão, sustenta Louden, consoante a Kant, que a conexão entre os princípios da ética pura e as ações propriamente ditas só poderia ser estabelecida levando-se em conta o conhecimento empírico da natureza humana, uma vez que "a ética não dá leis para ações [...], mas antes apenas para as máximas das ações". ${ }^{81}$ Como consequência, "se a lei pode ordenar apenas a máxima das ações e não as ações mesmas, então isso é um sinal de que ela deixa ao arbitrio livre uma margem (latitudo) para o cumprimento (observância) [da moralidade]", isto é, "não pode ser indicado de modo determinado como e em que medida deve-se atuar por meio da ação para o fim que é ao mesmo tempo dever". ${ }^{2}$

Aqui, a expressão fim que é ao mesmo tempo dever designa o chamado dever de virtude. Para Kant, ao passo que a virtude diria respeito meramente "ao elemento formal das máximas", o dever de virtude referir-se-ia "à matéria das mesmas, a saber, um fim [objeto]".83 Desse modo, ao passo que a "virtude, enquanto a conformidade da vontade com todo dever fundada na firme intenção [Gesinnung]"84 seria o elemento formal, os deveres de virtude, ao considerarem aquilo que "devemos propor como fim", teriam por objeto um "elemento material". 85 Com efeito, o dever de virtude trataria de um fim que nós ainda não temos, "mas que devemos ter". ${ }^{86}$ Portanto, haveria não somente "uma obrigação de virtude, mas muitos deveres de virtude".87 Decerto, "enquanto fundamento subjetivo da determinação, há apenas uma intenção [Gesinnung] virtuosa de cumprir seus deveres"88; porém, "o respeito pela lei em geral não funda ainda um fim enquanto dever", 89 mas trata tão-somente de uma relação de conformidade, isto é, "uma coerção segundo um princípio da liberdade interna".90

Em função disso, apenas a ética, em seu sentido formal (puro), não seria suficiente para prescrever em que medida dever-se-ia atuar por meio da ação em direção ao seu fim (que é ao mesmo tempo um dever). Não à toa, diz Kant haver uma divisão objetiva dos deveres para consigo mesmo, os quais diriam respeito tanto à "autoconservação moral" (deveres negativos, perfeitos, formais, restritivos) quanto ao "aperfeiçoamento de si mesmo" (deveres positivos para consigo mesmo, imperfeitos, materiais, extensivos). ${ }^{91}$ Os primeiros pertenceriam à "saúde moral do homem",92 tendo como principio a sentença: "conserve-se na perfeição de sua natureza";93 os segundos pertenceriam à "prosperidade moral", 94 e cuja proposição diria: "torne-se mais perfeito do que a mera natureza o fez". 95 De igual modo, os deveres éticos dos homens entre si seriam expressos tanto negativamente (por meio de proibições em relação a "vícios que violam o dever de respeito por outros homens"96) quanto positivamente (por meio de regras de aplicação "aos casos apresentados na experiência"97).

Assim, ao passo que "todos os deveres para consigo mesmo em vista do fim da humanidade em nossa própria pessoa são apenas deveres imperfeitos" (materiais, não puros), 98 "e isso graças à fragilidade (fragilitas) da natureza humana,"99 os

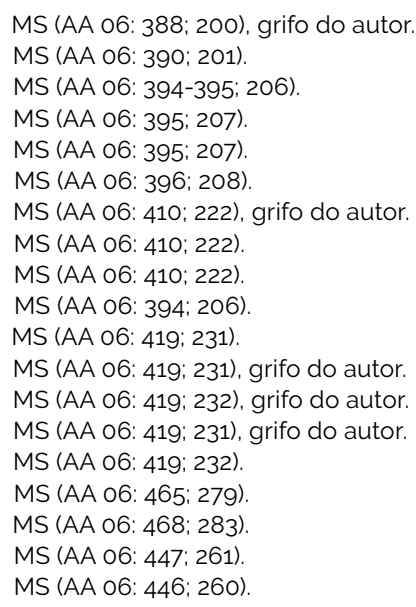


"deveres de virtude para com outros homens"100 não podem "de fato, dar lugar a um capítulo especial no sistema da ética pura, pois não contêm principios de obrigação dos homens, enquanto tais"101, mas "são apenas regras modificadas, segundo a variedade dos sujeitos, da aplicação dos princípios da virtude".102 Logo, a doutrina da virtude, ao considerar os fins que são ao mesmo tempo deveres (portanto, deveres de virtude conosco e para com os outros homens), consistiria tão-somente na tentativa de "aplicação da ética ao sensivel, ou melhor, ela apresenta[ria] os princípios de aplicação da ética à antropologia", ${ }^{103}$ uma vez que a "virtude (assim como a prudência) tem de ser aprendida da experiência".104 Nas palavras do próprio Kant,

[...] assim como se exige uma passagem da metafísica da natureza para a física, passagem que tem suas regras próprias, com todo direito reclama-se algo semelhante da metafísica dos costumes: por meio da aplicação dos princípios puros do dever a casos da experiência, por assim dizer, esquematizá-los e apresentá-los como prontos para o uso prático-moral. Portanto, qual comportamento convém aos homens, por exemplo, na pureza moral de seu estado ou na corrupção do mesmo, no estado cultivado ou rude; qual convém ao erudito ou ao não erudito, e qual convém àquele enquanto alguém sociável no uso de sua ciência (polido) ou enquanto alguém insociável (pedante) em sua profissão, enquanto alguém pragmático ou mais dado ao espírito e ao gosto; qual comportamento adotar segundo a variedade de estamentos, de idade. de gênero, de condição de saúde, de riqueza ou pobreza e assim por diante: isso tudo não fornece outras tantas espécies de obrigação ética (pois há só uma, a saber, a virtude em geral), mas apenas tipos de aplicação (porismas), que, portanto, não podem ser apresentados como seções da ética e membros da divisão de um sistema (que se tem de depreender a priori a partir de um conceito da razão), mas apenas podem ser anexados a este último. Entretanto, esta aplicação pertence, ela mesma, à completude da exposição de tal sistema. ${ }^{105}$

É sem sombra de dúvidas, pois, que a ética pura, enquanto sistema que tem de depreender a priori da razão, requer, para a sua completude, a exposição de sua aplicação por meio de uma antropologia moral, haja vista que, sem esta, nada se poderia saber a respeito da situação particular dos homens em relação à sua conduta in concreto. Consequentemente, "uma metafísica dos costumes não pode estar fundada na antropologia, mas pode ser aplicada a ela".106

Ainda que essa seja uma posição grandemente reivindicada em textos tardios (pós-1790), anotações de aulas e ensaios menores, além de passagens pontuais da Fundamentação e da segunda Crítica, aspectos disso podem ser identificados em textos de filosofia teórica como a própria Crítica da razão pura (1781/1787). Na Lógica Transcendental, por exemplo, afirma Kant que a lógica geral está para a lógica aplicada assim como a moral pura, que "contém apenas as necessárias leis morais de uma vontade livre em geral, está para o que é propriamente a doutrina das virtudes, que examina essas leis em relação aos obstáculos dos sentimentos, inclinações e paixões". ${ }^{107}$ Isso indica que, ao radicar as bases da filosofia moral já na primeira Crítica, ao mesmo tempo em que uma doutrina das virtudes é indicada enquanto campo de aplicação da moralidade (portanto, pertencente ao escopo da antropologia), vinculado ao aspecto sensivel humano, estaria Kant, desde um "nivel altamente abstrato", ${ }^{108}$ delineando aquilo que seria desenvolvido apenas anos mais tarde.

Louden identifica tal etapa como sendo um primeiro ponto-chave (o da ética pura em sentido mais especulativo), a partir do qual a filosofia crítica se articularia em direção à ética impura, fazendo surgir, portanto, o que ele denomina de fields of impurity, ${ }^{109}$ ou seja, esferas de ação ou aplicação da moral segundo graus de sensibilidade. Tais niveis seriam, respectivamente, o da

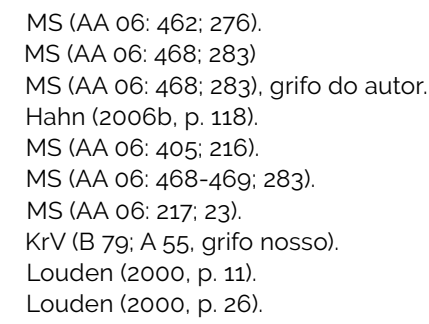


Fundamentação, com a introdução do imperativo categórico, ilustrado por meio de "suposições sobre negociantes demasiado humanos, dinheiro, devedores, e assim por diante"110, isto é, "dados relativos à natureza e à cultura humanas";111 o da Crítica da razão prática, a qual supõe que a "determinação particular dos deveres, enquanto deveres humanos, [...] só é possivel se o sujeito dessa determinação (o homem) for previamente conhecido segundo a constituição com a qual ele se efetiva"112, ainda que essa determinação não pertença "a uma crítica da razão prática em geral, que deve fornecer de maneira completa apenas os princípios de sua possibilidade, de sua extensão e de seus limites, sem referência particular à natureza humana",113 o da Metafísica dos costumes, a qual toma como objeto frequente a "natureza particular do homem, cognoscivel apenas pela experiência, para nela mostrar as conclusões dos princípios morais universais sem por meio disso tirar algo da pureza dos últimos, nem pôr em dúvida sua origem a priori".114

No interior desse grande mapa, por sua vez, encontrar-se-ia anexada uma série de questões especificas, não apenas voltadas aos tipos de obrigação e a sua relação com a natureza particular do homem, mas muitas outras situações, como a possibilidade de uma educação moral, o estudo de obstáculos relativos à impressão de principios morais na espécie, bem como o papel das instituições frente à ideia de um progresso civilizacional. São elas:115 a) "como os principios morais devem ser ensinados aos seres humanos?"; b) "dado o que sabemos sobre o desenvolvimento humano, em quais etapas da vida humana as pessoas deveriam aprender sobre moralidade e como deveriam aprender sobre isso?"; c) a "que paixões e inclinações especificas estão os seres humanos sujeitos e que tendem a dificultar (ou facilitar) sua adesão aos principios morais?"; d) "existem aspectos culturais especificos da era moderna que tornam o estabelecimento da 'regra do direito' mais ou menos provável do que em épocas anteriores?"; e) "em que estágio do desenvolvimento moral está a própria raça humana no presente?"; f) "como devem as instituições politicas, culturais, educacionais e religiosas ser organizadas para melhores objetivos morais?".

Segundo Louden, "a possibilidade de uma resposta a qualquer uma dessas questões requerleria] uma quantidade muito maior de informações empíricas do que a permitida no projeto de 'determinação dos deveres' da Metafisica dos costumes".116 Eis porque, ao considerarmos obras como A religião nos limites da simples razão (1793), partes da Crítica da faculdade de julgar (1790), Antropologia de um ponto de vista pragmático (1798), Sobre a pedagogia (1803) e muitos dos ensaios mais curtos sobre a história, 117 torna-se visivel não apenas uma preocupação moral fundamental, bem como a apreciação de muitos dos aspectos empíricos gradualmente implicados nas obras mais capitais dedicadas à filosofia prática, mas também uma ampliação do seu campo de problemas, os quais, em grande medida, elaboram novas perguntas e extrapolam o campo metafísico da ética propriamente dito. Assim sendo, o julgamento a respeito do que fazer em situações especificas teria por objeto todas essas questões que a simples derivação dos deveres de virtude não poderia por si só responder, uma vez que tais situações fariam parte da própria constituição da vivência humana em sentido mais amplo, pensada como gênero e sociedade civil.

Logo, as três primeiras questões ('a', 'b' e 'c') diriam respeito tanto à pedagogia, a qual

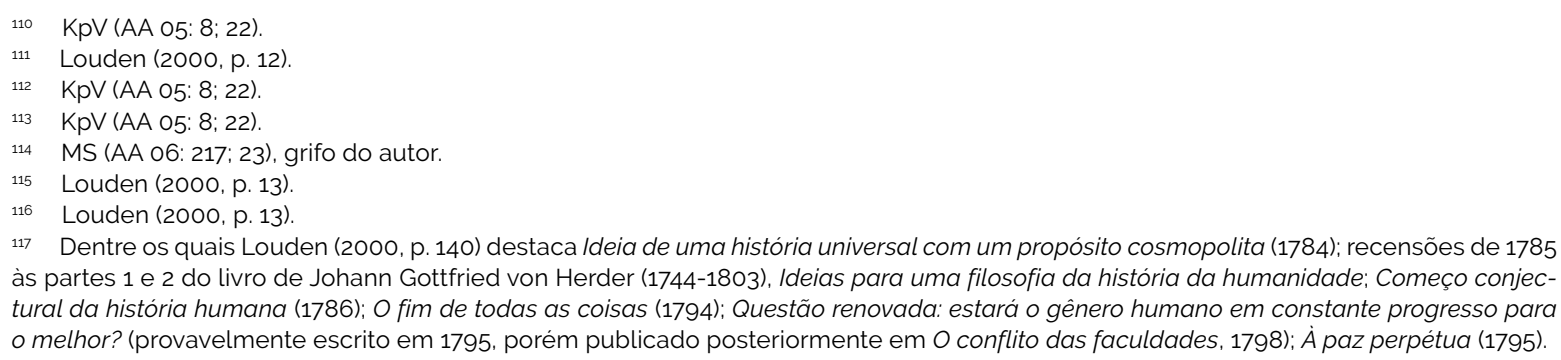

Dentre os quais Louden (2000, p. 140) destaca Ideia de uma história universal com um propósito cosmopolita (1784); recensões de 1785 às partes 1 e 2 do livro de Johann Gottfried von Herder (1744-1803), Ideias para uma filosofia da história da humanidade; Começo conjectural da história humana (1786); O fim de todas as coisas (1794); Questão renovada: estará o gênero humano em constante progresso para o melhor? (provavelmente escrito em 1795, porém publicado posteriormente em O conflito das faculdades, 1798); À paz perpétua (1795). 
consistiria na "estratégia de educação moral através do treinamento das habilidades do julgar prático", quanto à antropologia pragmática, tomada enquanto estudo "dos subgrupos raciais e de gênero" e da "importância da universalidade da ética"; 118 as três últimas ('d', 'e' e 'f') integrariam tanto o quadro de reflexões acerca da história e seus pressupostos jurídico-políticos, onde se enfatiza "a concepção de progresso histórico como um desenvolvimento em direção a uma sociedade cosmopolita", quanto o que se refere à arte e à religião e a necessidade de saber, por meio destas, como "a apreciação estética serve aos propósitos da moralidade e como as instituições religiosas auxiliam a construção de uma comunidade moral global". ${ }^{119}$

Nesse sentido, "o locus especifico da antropologia moral"120 residiria justamente na tentativa de responder, mediante um conhecimento empírico acerca do gênero humano (e não apenas do homem individual), em que medida os princípios da moralidade poderiam se tornar, de fato, eficazes na vida humana, a fim de nos fazer "pessoas moralmente melhores". ${ }^{121}$ O exame detalhado de cada uma dessas doutrinas e seus desdobramentos segundo Kant, porém, exigiria a consecução de um trabalho à parte, o qual julgamos exceder os limites da presente pesquisa, haja vista o semnúmero de referências e abordagens que o tema naturalmente suscita. Ainda assim, não resta dúvidas quanto a relevância e convergência dos estudos antropológicos kantianos e sua inegável importância na elaboração de uma segunda parte da filosofia moral, sem os quais a parte pura existiria meramente como ideia problemática, isto é, cuja realidade objetiva não poderia ser de maneira alguma conhecida.

\section{Referências}

BONACCINI, Juan Adolfo. Antropologia, ciência da natureza humana "por analogia". Kant e-Prints, Campinas, v. 5. n. 3, pp. 145-161, jul./dez. 2010.
BORGES, Maria de Lourdes. A redescoberta da Antropologia de Kant. In: BORGES, Maria de Lourdes (org.) Comentários sobre a Antropologia de um ponto de vista pragmático de Kant. Florianópolis: Nefiponline, 2018a.

BORGES, Maria de Lourdes. Kant's impure ethics, de Robert Louden. Kant e-Prints, Campinas, v. 2, n. 3, p. 1-5, $2003 \mathrm{~b}$.

BORGES, Maria de Lourdes. Psicologia empírica, antropologia e metafísica dos costumes em Kant. Kant e-Prints, Campinas, v. 2, n. 1, p. 1-10, 2003 a.

BORGES, Maria de Lourdes. Psicologia empírica, antropologia e metafísica dos costumes em Kant. In: BORGES, Maria de Lourdes (org.). Comentários sobre a Antropologia de um ponto de vista pragmático de Kant. Florianópolis: Nefiponline, 2018b.

BORGES, Maria de Lourdes. The metaphysics of morals: between the a priori and a practical anthropology. Ethic@, Florianópolis, v. 16, n. 3, p. 423-436, dez. 2017 https://doi.org/10.5007/1677-2954.2017v16n3p423.

BRANDT, Reinhard. Kritischer Kommentar zu Kants Anthropologie in pragmatischer Hinsicht (1798). Hamburg Felix Meiner Verlag, 1999. (Kant-Forschungen, Band 10).

CUNHA, Bruno Leonardo; FELDHAUS, Charles. Estudo introdutório. In: KANT, Immanuel. Lições de ética. Tradução de Bruno Leonardo Cunha e Charles Feldhaus. São Paulo: Editora Unesp Digital, 2018.

FIRLA, Monika. Untersuchungen zum Verhältnis von Anthropologie und Moralphilosophie bei Kant. Frankfurt am Main: Peter Lang, 1981

FRIERSON, Patrick R. Freedom and anthropology in Kant's moral philosophy. Cambridge: Cambridge University Press, 2003

HAHN, Alexandre. A função da antropologia moral na filosofia prática de Kant. 255 p. Tese (Doutorado em Filosofia) - Instituto de Filosofia e Ciências Humanas, Universidade Estadual de Campinas, Campinas, 2010.

HAHN, Alexandre. Antropologia pragmática como conhecimento do mundo em Kant. In: CORREIA, Adriano; HAMM, Christian; PEREZ, Daniel Omar (org.). Kant. São Paulo: ANPOF, 2017.

HAHN, Alexandre. Aspectos fundamentais da problemática semântica na doutrina da virtude de Kant. Kant e-Prints, Campinas, v. 1, n. 1, p. 57-88, jan.-jun. 2006 a.

HAHN, Alexandre. Como são possiveis deveres de virtude em Kant? Trans/Form/Ação, São Paulo, v. 29, n. 2, p. 115-121, 2006b. https://doi.org/10.1590/S0101-31732006000200009

KANT, Immanuel. (AA): Gesammelte Schriften. Bd 1-22 hrsg. von der Preussischen Akademie der Wissenschaften, Bd 23 von der Deutschen Akademie der Wissenschaften zu Berlin, ab Bd 24 von der Akademie der Wissenschaften zu Göttingen. Berlln: Walter de Gruyter, 1900-.

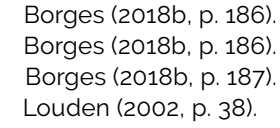


KANT, Immanuel. (Anth): Antropologia de um ponto de vista pragmático. Tradução de Clélia Aparecida Martins. São Paulo: Iluminuras, 2006.

KANT, Immanuel. (GMS): Fundamentação da metafísica dos costumes. Tradução de Paulo Quintela. Lisboa: Edições 70, 2007.

KANT, Immanuel. (KpV): Crítica da razão prática. Tradução de Monique Hulshof. Petrópolis: Vozes; Bragança Paulista: Editora Universitária São Francisco, 2016b.

KANT, Immanuel. (KrV): Crítica da razão pura. Tradução de Manuela Pinto dos Santos e Alexandre Fradique Morujão. 5.ed. Lisboa: Fundação Calouste Gulbenkian, 2001.

KANT, Immanuel. (KU): Crítica da faculdade de julgar. Tradução de Fernando Costa Mattos. Petrópolis: Vozes; Bragança Paulista: Editora Universitária São Francisco, 2016a.

KANT, Immanuel. (Log): Lógica: [Excertos da] introdução. Tradução de Artur Morão. Covilhã: LusoSofia:press, 2009.

KANT, Immanuel. (MS): Metafísica dos costumes. Tradução de Clélia Aparecida Martins, Bruno Nadai, Diego Kosbiau e Monique Hulshof. Petrópolis: Vozes; Bragança Paulista: Editora Universitária São Francisco, 2013.

KANT, Immanuel. (TP): Sobre a expressão corrente: isto pode ser correcto na teoria, mas nada vale na prática. Tradução de Artur Morão. Covilhã: Lusosofia, s.d. Disponivel em: https://www.marxists.org/portugues/ kant/1793/mes/corrente.pdf. Acesso em: 15 set. 2018.

KANT, Immanuel. (V-Anth/Fried; V-Anth/Mensch): Cursos de antropologia: a faculdade de conhecer (excertos). Seleção, tradução e notas de Márcio Suzuki. São Paulo: Editora Clandestina, 2017.

KANT, Immanuel. (V-Mo/Collins): Lectures on ethics. Edited by Peter Heath and J. B. Schneewind. Translated by Peter Heath. Cambridge: Cambridge University Press, 1997

KANT, Immanuel. (VvRM): Das diferentes raças humanas. Tradução de Alexandre Hahn. Kant e-Prints, Campinas, v. 5, n. 5, p. 10-26, jul.-dez. 2010.

KLEIN, Joel Thiago. A questão da teleologia: Kant leitor de Rousseau. Cadernos de Filosofia Alemã, São Paulo, v. 22, n. 1, p. 51-70, jan.-jun. 2017b. https://doi. org/10.11606/issn.2318-9800.v22i1p51-70

KLEIN, Joel Thiago. A relação entre ética e direito na filosofia politica de Kant. Manuscrito, Campinas, v. 37, n. 1, p. 161-210, jun. 2014. https://doi.org/10.1590/S010060452014000100005

KLEIN, Joel Thiago. A sociabilidade insociável e a antropologia kantiana. Rev. Filos. Aurora, Curitiba, v. 25, n. 36, p. 265-285, jan.-jun. 2013a. https://doi.org/10.7213/ revistadefilosofiaaurora. 7774

KLEIN, Joel Thiago. Kant e a ideia de uma história universal nos limites da razão. 353 p. Tese (Doutorado em Filosofia) - Centro de Filosofia e Ciências Humanas, Universidade Federal de Santa Catarina, Florianópolis, 2012.

KLEIN, Joel Thiago. Kant sobre o progresso na história. Ethic@, Florianópolis, v. 12, n. 1, p. 67-100, jun. 2013b. https://doi.org/10.5007/1677-2954.2013v12n1p67
KLEIN, Joel Thiago. O Estado republicano democrático e o ensino público da moral segundo Kant. Discurso, São Paulo, v. 46, n. 2, p. 85-122, 2016.

KLEIN, Joel Thiago. O problema da fundamentação de uma história universal no sistema crítico-transcendental de Kant. 142 p. Dissertação (Mestrado em Filosofia) Centro de Ciências Sociais e Humanas, Universidade Federal de Santa Maria, Santa Maria, 2008.

KLEIN, Joel Thiago. Prudência e moral na filosofia política de Kant. Estudos Kantianos, Marília, v. 5, n. 1, p 159-178, jan.-jun. 2017c. https://doi.org/10.36311/23180501.2017.v5n1.12.p159

KLEIN, Joel Thiago. Reflexão teleológica e o caráter da espécie humana na antropologia de um ponto de vista pragmático. In: BORGES, Maria de Lourdes (org.). Comentários sobre a Antropologia de um ponto de vista pragmático de Kant. Florianópolis: Nefiponline, 2018.

LEONEL Ribeiro dos Santos. Disponivel em: https:// sites.google.com/site/Lrs1947/. Acesso em: 14 jan. 2019

LOPARIC, Zeljko. As duas metafísicas de Kant. Kant e-Prints, Campinas, v. 2, n. 5, 2003a. https://doi. org/10.5380/dp.v2i2.1964

LOPARIC, Zeljko. Kant e o pretenso direito de mentir. Kant e-Prints, Campinas, Série 2, v. 1, n. 2, p. 57-72, jul.-dez. 2006.

LOPARIC, Zeljko. Kant entre o ficcionalismo de Vaihinger e a fenomenologia de Heidegger. APRENDER - Cad. de Filosofia e Psic. da Educação, Vitória da Conquista, ano VI, n. 10, pp. 73-100, 2008a.

LOPARIC, Zeljko. Natureza humana como domínio de aplicação da religião da razão. Kant e-Prints, Campinas, Série 2, v. 2, n. 1, pp. 73-91, jan.-jun. 2007.

LOPARIC, Zeljko. O problema fundamental da semântica juridica de Kant. 2003b. Disponivel em: http://interleft. com.br/loparic/zeljko/pdfs/problema_kant_97_114. pdf. Acesso em: 15 jan. 2019

LOPARIC, Zeljko. Os problemas da razão pura e a semântica transcendental. DoisPontos, Curitiba, v. 2, n. 2, p. 113-128, out. 2005

LOPARIC, Zeljko. Solução kantiana do problema fundamental da religião. In: PERES, Daniel Tourinho et al (org.). Tensões e passagens - Filosofia critica e modernidade. São Paulo: Singular/Esfera Pública, 2008b.

LOUDEN, Robert B. A segunda parte da moral: a antropologia moral de Kant e sua relação com a metafísica dos costumes. Ethic@, Florianópolis, v. 1, n. 1, p. 27-46, jun. 2002.

LOUDEN, Robert B. Kant's impure ethics: from rational beings to human beings. New York: Oxford University Press, 2000

MARTINS, Clélia Aparecida. A antropologia de um ponto de vista pragmático e a filosofia política de Kant. In: BORGES, Maria de Lourdes (org.). Comentários sobre a Antropologia de um ponto de vista pragmático de Kant. Florianópolis: Nefiponline, 2018. 
MARTINS, Clélia Aparecida. A antropologia kantiana e a antropologia de um ponto de vista pragmático. Discurso, São Paulo, n. 34, p. 125-144, 2004. https:// doi.org/10.11606/issn.2318-8863.discurso.2004.62838

NAHRA, Cinara. Sobre o aperfeiçoamento moral como destino da espécie humana. In: BORGES, Maria de Lourdes (org.). Comentários sobre a Antropologia de um ponto de vista pragmático de Kant. Florianópolis: Nefiponline, 2018

OLIVEIRA SILVA, Reginaldo. Dialética natural e analítica da moralidade em Immanuel Kant. Aurora, Curitiba, v. 28 , n. 44 , p. 551-571, maio/ago. 2016. https://doi. org/10.7213/aurora.28.044.DSO8

PATON, Herbert James. The categorical imperative: a study in Kant's moral philosophy. London: Hutchinson's University Library, 1946.

PEREZ, Daniel Omar. A antropologia pragmática como parte da razão prática em sentido kantiano. Manuscrito Rev. Int. Fil., Campinas, v. 32, n. 2, pp. 357-397, jul.-dez. 2009.

PEREZ, Daniel Omar. A proposição fundamental da antropologia pragmática e o conceito de cidadão do mundo em Kant. In: FAGGION, Andréa; REIS, Róbson Ramos dos (org.). Um filósofo e a multiplicidade dos dizeres: homenagem aos 70 anos de vida e 40 de Brasil de Zeljko Loparic. Campinas: Unicamp/CLE, 2010a.

PEREZ, Daniel Omar. A relação entre a teoria do juizo e natureza humana em Kant. Educação e Filosofia, Uberlândia, v. 27, n. especial, p. 233-258, 2013a. https://doi.org/10.14393/ REVEDFIL.issn.0102-6801.V27nEspeciala2013-p233a258

PEREZ, Daniel Omar. Conceitos de antropologia fisiológica na antropologia kantiana: Kant e os naturalistas em um debate sobre a natureza humana. In: BECKENKAMP, Joãosinho; FAGGION, Andrea (org.). Temas semânticos em Kant. São Paulo: DWW, 2013b.

PEREZ, Daniel Omar. Foucault como kantiano: acerca de um pensamento do homem desde sua própria finitude. Rev. Filos. Aurora, Curitiba, v. 24, n. 34, p. 217239, jan.-jun. 2012

PEREZ, Daniel Omar. Los límites de la psicología como ciencia y la posibilidad de su uso en la antropología en Kant. Studia Kantiana, Natal, v. 15, n. 2, p. 51-61, ago. 2017 a.

PEREZ, Daniel Omar. O lugar da natureza humana em Kant. Natureza Humana, São Paulo, v. 19, n. 2, p. 3-19, dez. 2017b.

PEREZ, Daniel Omar. O projeto antropológico de Kant. In: BORGES, Maria de Lourdes (org.). Comentários sobre a Antropologia de um ponto de vista pragmático de Kant. Florianópolis: Nefiponline, 2018.

PEREZ, Daniel Omar. O significado de natureza humana em Kant. Kant e-Prints, Campinas, v. 5, n. 1, pp. 75-87, jan.-jun. 2010b.

SCHMIDT, Claudia M. Kant's transcendental, empirical, pragmatic, and moral anthropology. Kant-Studien (Internet), v. 98, n. 2, pp. 156-182, jul. 2007.
SIPERT, Cláudio. A modificação de sentido do sumo bem na filosofia tardia de Kant. 212 p. Tese (Doutorado em Filosofia) - Instituto de Filosofia e Ciências Humanas, Universidade Estadual de Campinas, Campinas, 2013.

WOOD, Allen. Kant's ethical thought. Cambridge: Cambridge University Press, 1999.

\section{Felipe Rodrigues Simões}

Doutorando no Programa de Pós-Graduação em Filosofia pela Universidade Federal do Rio Grande do Norte (UFRN), Natal, RN, Brasil.

\section{Endereço para correspondência}

Felipe Rodrigues Simões

Universidade Federal do Rio Grande do Norte

Avenida Senador Salgado Filho, 3.000, sala 9. S/N Centro de Convivência Djalma Marinho.

Natal, RN, Brasil. 